\title{
Correction to: Pharmacokinetics of Hormonal Contraception in Individuals with Obesity: a Review
}

\author{
Shaalini Ramanadhan ${ }^{1} \cdot$ William J. Jusko ${ }^{2} \cdot$ Alison Edelman ${ }^{1}$ \\ Published online: 10 December 2020 \\ (C) Springer Science+Business Media, LLC, part of Springer Nature 2020
}

\section{Correction to: Curr Obstet Gynecol Rep (2020) 9:72-78. https://doi.org/10.1007/s13669-020-00284-y}

The original version of this article unfortunately contained some mistakes.

In Table 2 and Table 3, complete and correct bibliographical information especially for the missing works of Foegh 2013 [31], Westhoff 2012 [32], Segall-Gutierrez 2010 [33], Sivin 1997 [34], Sivin 2001 [35], Mornar 2012 [36], Hidalgo 2009 [37] and Seeber 2012 [38] are hereby listed as part of the Reference List.

27. Doose DR, Wang SS, Padmanabhan M, Schwabe S, Jacobs D, Bialer M. Effect of topiramate or carbamazepine on the pharmacokinetics of an oral contraceptive containing norethindrone and ethinyl estradiol in healthy obese and nonobese female subjects. Epilepsia. 2003;44(4):540-9.

28. Edelman AB, Carlson NE, Cherala G, Munar MY, Stouffer RL, Cameron JL, et al. Impact of obesity on oral contraceptive pharmacokinetics and hypothalamic-pituitary-ovarian activity. Contraception. 2009;80(2):119-27.

29. Westhoff CL, Torgal AH, Mayeda ER, Pike MC, Stanczyk FZ. Pharmacokinetics of a combined oral contraceptive in obese and normal-weight women. Contraception. 2010;81(6):474-80.

The online version of the original article can be found at https://doi.org/ $10.1007 / \mathrm{s} 13669-020-00284-\mathrm{y}$

Shaalini Ramanadhan ramanadh@ohsu.edu

1 Oregon Health \& Science University, Portland, OR 97239, USA

2 Department of Pharmaceutical Sciences, University at Buffalo, Buffalo, NY 14214, USA
30. Edelman AB, Cherala G, Munar MY, Dubois B, McInnis M, Stanczyk FZ, et al. Prolonged monitoring of ethinyl estradiol and levonorgestrel levels confirms an altered pharmacokinetic profile in obese oral contraceptives users. Contraception. 2013;87(2):220-6.

31. Foegh M, Archer DF, Stanczyk FZ, Rubin A, Mishell DR. Ovarian activity in obese and nonobese women treated with three transdermal contraceptive patches delivering three different doses of ethinyl estradiol and levonorgestrel. Contraception. 2013;87(2):201-11.

32. Westhoff CL, Torgal AH, Mayeda ER, Petrie K, Thomas T, Dragoman M, et al. Pharmacokinetics and ovarian suppression during use of a contraceptive vaginal ring in normal-weight and obese women. American Journal of Obstetrics and Gynecology. 2012;207(1):39.e1-.e6.

33. Segall-Gutierrez P, Taylor D, Liu X, Stanzcyk F, Azen S, Mishell DR. Follicular development and ovulation in extremely obese women receiving depo-medroxyprogesterone acetate subcutaneously. Contraception. 2010;81(6):487-95.

34. Sivin I, Lähteenmäki P, Ranta S, Darney P, Klaisle C, Wan $\mathrm{L}$, et al. Levonorgestrel concentrations during use of levonorgestrel rod (LNG ROD) implants. Contraception. 1997;55(2):81-5.

35. Sivin I, Wan L, Ranta S, Alvarez F, Brache V, Mishell $\mathrm{DR}$, et al. Levonorgestrel concentrations during 7 years of continuous use of Jadelle contraceptive implants. Contraception. 2001;64(1):43-9.

36. Mornar S, Chan L-N, Mistretta S, Neustadt A, Martins S, Gilliam M. Pharmacokinetics of the etonogestrel contraceptive implant in obese women. AJOG. 2012;207(2):110.e1-.e6.

37. Hidalgo MM, Hidalgo-Regina C, Bahamondes MV, Monteiro I, Petta CA, Bahamondes L. Serum levonorgestrel levels and endometrial thickness during extended use of the levonorgestrel-releasing intrauterine system. Contraception. 2009. July;80(1):84-9. 
38. Seeber B, Ziehr SC, Gschließer A, Moser C, Mattle V, Seger C, et al. Quantitative levonorgestrel plasma level measurements in patients with regular and prolonged use of the levonorgestrel-releasing intrauterine system. Contraception. 2012;86(4):345-9.

39. Westhoff CL, Reinecke I, Bangerter K, Merz M. Impact of body mass index on suppression of follicular development and ovulation using a transdermal patch containing 0.55-mg ethinyl estradiol/2.1-mg gestodene: a multicenter, open-label, uncontrolled study over three treatment cycles. Contraception. 2014;90(3):272-9. A study investigating PK parameters for the steroid hormone components of a transdermal contraceptive patch, demonstrating that even in individuals with obesity, ovulation was consistently inhibited with the patch.

40. Creinin MD, Baker JB, Eisenberg DL, Ginde S, Turok DK, Westhoff CL. Levonorgestrel levels in nonobese and obese women using LNG20, a new intrauterine contraceptive. Obstet Gynecol. 2015;125:84S-5S.

41.•-Luo D, Westhoff CL, Edelman AB, Natavio M, Stanczyk FZ, Jusko WJ. Altered pharmacokinetics of combined oral contraceptives in obesity - multistudy assessment.
Contraception. 2019;99(4):256-63. A study aggregating data from multiple PK studies demonstrating minor changes in PK parameters for the steroid hormones in oral contraceptive pills. Trough levels for hormones were found to be the same in individuals with and without obesity.

42. Edelman AB, Cherala G, Blue SW, Erikson DW, Jensen JT. Impact of obesity on the pharmacokinetics of levonorgestrel-based emergency contraception: single and double dosing. Contraception. 2016;94(1):52-7. This study shows that double dosing of LNG emergency contraception in individuals with obesity may remedy the lack of efficacy of single LNG EC doses in this population.

43. Edelman AB, Cherala G, Munar MY, McInnis M, Stanczyk FZ, Jensen JT. Correcting oral contraceptive pharmacokinetic alterations due to obesity: a randomized controlled trial. Contraception. 2014;90(5):550-6.

Publisher's Note Springer Nature remains neutral with regard to jurisdictional claims in published maps and institutional affiliations. 